\title{
IAMJ
}

INTERNATIONAL

AYURVEDIC

MEDICAL JOURNAL

ISSN: 2320-5091

Impact Factor: 6.719

\section{SCIENTIFIC STUDY OF VITAP MARMA}

\section{Rajesh Kumar', Mahesh Kumar ${ }^{2}$, Santosh Kumar Singh ${ }^{3}$, S.S. Gupta ${ }^{4}$}

${ }^{1}$ P.G. Scholar, Dept. of Rachana Sharir, Government Ayurvedic College and Hospital, Kadamkuan, Patna-3, Bihar, India

${ }^{2}$ P.G. Scholor, Dept. of Rachana Sharir, Government Ayurvedic College and Hospital, Kadamkuan, Patna-3, Bihar, India

${ }^{3}$ Assistant Professor, Dept. of Rachana Sharir, Government Ayurvedic College and Hospital, Kadamkuan, Patna-3, Bihar, India

${ }^{4}$ Professor and Head, Dept. of Rachana Sharir, Government Ayurvedic College and

Hospital, Kadamkuan, Patna-3, Bihar, India

Corresponding Author:rudradev201655555@gmail.com

https://doi.org/10.46607/iamj1509122021

(Published Online: December 2021)

Open Access

(C) International Ayurvedic Medical Journal, India

Article Received:03/11//2021 - Peer Reviewed:28/11/2021 - Accepted for Publication03/12/2021

\section{Check for updates}

\section{ABSTRACT}

Marma is a vital point of the body where trauma or injury may cause a various range of signs and symptoms from Ruja (pain) to even death. Ayurvedic Acharya's has explained 107 Marma" that are present in the anterior and posterior aspect of the human body. Depending upon the effect of injury on Marma is five types like Sadhyo pranhara, Kalantara pranhara, Vishlyaghna, Vaikalykara \& Rujakara Marma. Out of them, Vaikalykar Marma are the points where an injury causes structural or functional deformity. Another type of classification of Marma has also been made as Mamsa (muscle) marma, Sira (artery/vein) marma, Snayu (ligament) marma, Asthi (bone) marma and Sandhi (joint) marma. The Vitap Marma is placed under the Snayu Marma by Acharya Sushrut and Sira Marma by Acharya Vaghbhata. Vitap Marma is situated between Vankshan (Groin) and Vrishna (Testes) and the Viddha lakshan (symptoms of trauma) is Shandata (impotency) and Alpashukrata (oligospermia). The structure present at this point is the inguinal canal. The clinical importance of the inguinal canal is related to the ingui- 
nal hernia. Direct or indirect Injury at this particular point affects the physiology of the reproductive system and may cause sterility, which is similar to Viddha lakshan of Vitap marma as described by Sushrut.

Keywords: Vitap marma, Vaikalyakar marma, Inguinal canal, Spermatic cord, round ligament

\section{INTRODUCTION}

Saptottaram Marmashatam shariram. (Su. sha. -6/3)

Acharya Sushrut has identified 107 Marma. ${ }^{1}$

Following the Sushrut another sage of Ayurveda has also mentioned 107 Marma.

Marmani nam Mansa Shira Snayu Asthi Sandhi Sannipatah, tesu swabhawat ev visheshen pranah tishthanti. (Su. sha. -6/16)

Marma (vital points) is the site where a conglomera-

tion of
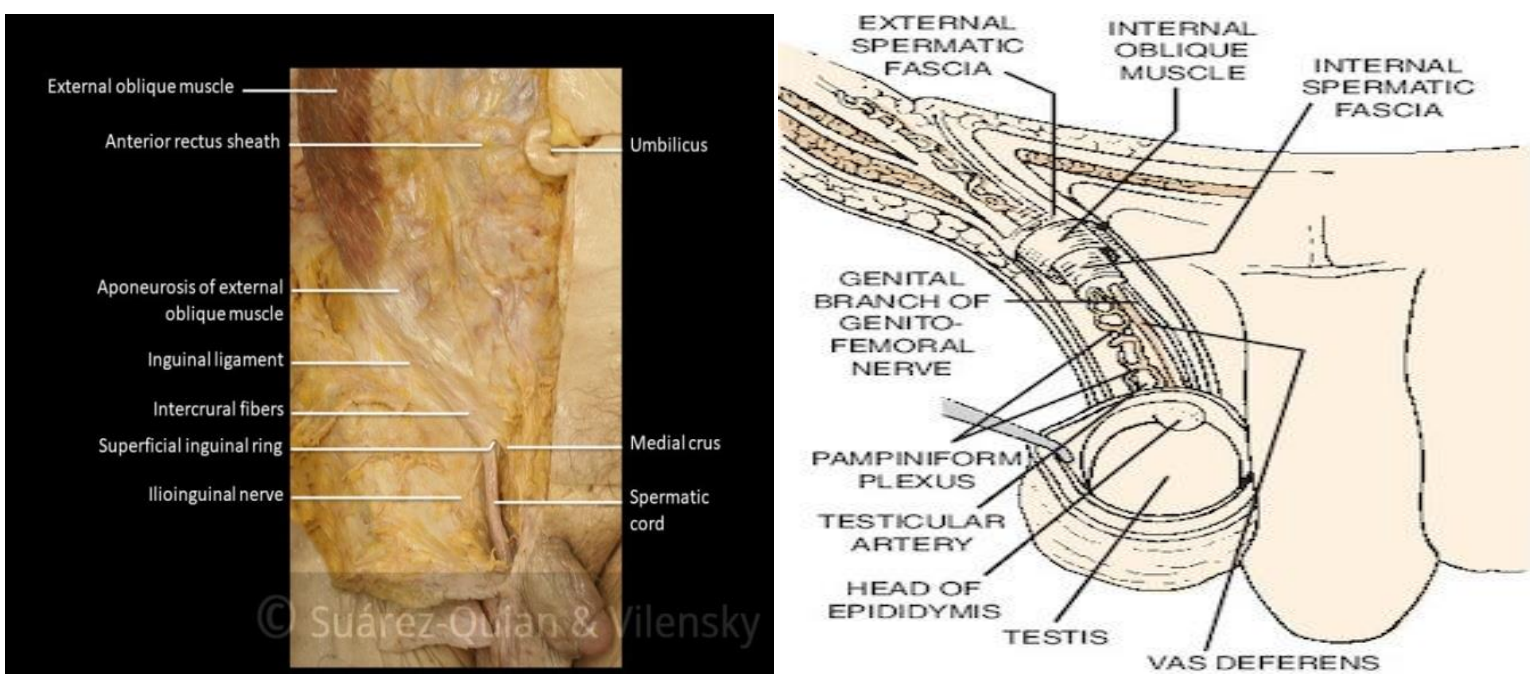

Marma has great value during a surgical procedure. Before performing any surgical procedure broad range of knowledge about Marma and Marmabhighata (injury to the Vital points) should be known.

\section{AIM \& OBJECTIVE -}

- Structural exploration of Vitap marma in accordance with Maharsi Sushrut and modern view.

- Observation and Analysis of the resultants obtained from Marmabhighata of Vitap marma.

- To observe the importance of the content of Vitap marma. teric fascia and internal spermatic fascia.
Mamsa (Muscle), Sira (vein/arteries), Snayu (ligaments), Asthi (bones) and Sandhi (joints). At this point, Prana resides. ${ }^{2}$ Dr.Ghanekar said that the inguinal canal is the site of Vitap Marma, and this is an Adhosakhagata Marma3. In Urdhwashakhagata same is replaced by "Kakshadhara Marma”. Marma sharir is one of the specialities of Ayurveda.

\section{ANATOMICAL STRUCTURE RELATED TO VITAP MARMA-}

Dr Ghanekar says Vitap Marma is the site of inguinal canal ${ }^{4}$ whose content is a spermatic cord in the male and round ligament in female and ilioinguinal nerve. The content of the spermatic cord is pampiniform plexus of the vein, testicular artery, cremasteric artery, artery of ductus deferens, genitofemoral nerve, ductus deference and lymph vessels. Covering of spermatic cord is external spermatic fascia, cremas-

Pampiniform plexus is a venous return from the testis to drain the testicular vein, helping to regulate the temperature of the testis which is essential for sper- 
matogenesis. Testicular arteries are lateral branches of the abdominal aorta, which supplies blood to the testis. The cremasteric artery is a branch of the inferior epigastric artery and supplies blood to the cremasteric muscle and covering of the spermatic cord. The ductus deferens is a duct that transfers sperm from the epididymis to the ejaculatory duct. The genitofemoral nerve is a branch of the lumbar plexus and supplies sensation to the upper anterior scrotum in the male. The ilioinguinal nerve supplies sensory fibres to the transversus abdominis and internal oblique muscle. It also supplies the anteromedial aspect of the skin of the thigh. The skin covering the upper scrotum and the skin over the root of the penis in the male are representative of the skin over the mons pubis and labium majora in females. ${ }^{5}$

\section{DISCUSSION}

Vitap Marma is Vaikalyakara Marma. It lies between Vrishna (testes) and Vankshan (groin). According to modern Anatomy, the Inguinal canal is there through which the Spermatic cord present passes to come into the abdomen to take the secretion of seminal vesicle and prostate gland. Shusrut said that injury on this Marma develops Alpshukrata (oligospermia) and ultimately Shandata (impotency). Every content of the spermatic cord can develop such a defect as described by Sushrut.

1. Testicular Artery - The main function of this artery is to provide blood supply to $2 / 3^{\text {rd }}$ of the testes. Injury of this artery results in improper nutritional supply to the testis, which may affect the decreased production of sperm which may cause impotency or oligospermia.

2. Cremasteric Artery - It accompanies by the spermatic cord and supply the cremaster muscle and other covering of the spermatic cord. Injury to this arteryresults in improper/insufficient blood supply to the cremaster muscle which hampers its contraction and relaxation action and proper cremasteric reflex. Which is a necessary act for thermoregulation and spermatogenesis. Ultimately may cause impotency or oligospermia.
3. Artery Of Ductus Deferens - The artery to the ductus deferens (deferential or vesiculo deferential artery) is an artery in males that provides blood to the ductus deferens and arises from the superior vesical artery which in turn arises from the anterior branch of the internal iliac artery via an umbilical artery. It supplies ductus deferens and provides proper function. It continues along the ductus deferens to mobile the immobile sperm by contraction of ductus deferens. It continues as the tissue lining of the inside wall moist the folded layer of the mucous membrane, and this is properly performed by this arterial supply. Surrounding the mucous membrane there are three layers of circular and longitudinal muscle fibre. These fibres cause the ducts to control and thus allow the sperms and fluid to be transported. Damage to this artery affects the blood supply and ultimately due to lack of proper nutrition layer may emaciate and fail to moist properly. This will affectthe sperm movement which causes Alpshukrata (oligospermia) and Shandata (impotency).

4. Pampiniform Plexus - It emerges from the mediastinum testis and ascends within the spermatic cord and further travels through the inguinal canal to enter the abdominal cavity as a testicular vein. As the veins of the pampiniform plexus climb up the spermatic cord, they surround the testicular artery. In this way, the relatively cool venous blood helps to lower the temperature of the warmer arterial blood in the testicular artery. This vascular arrangement of pampiniform plexus contributes to the function of thermoregulation of the testes and helps to maintain an appropriate temperature for spermatogenesis. Injury over this area causes the development of an imbalance in thermoregulation for spermatogenesis which ultimately results in Shandata (impotency) and Alpshukrata (oligospermia).

5. Genitofemoral Nerve - Branch of genitofemoral nerve supplies motor fibres to cremaster and dartous muscle, which elevates and lowers the testes. The sensory fibres from the nerve in the upper thigh react to gentle stimulation and signal the sensory fibres that cause the testicle muscles to contract and raises the testes. Injury to this nerve causes not properly raises 
or lower down of testes which is necessary for better spermatogenic condition and ultimately cause impotency or oligospermia.

6. Ductus Deferens - Ductus deferens serve a dual function in the male reproductive system. Transporting sperm from the epididymis to the ejaculatory duct and urethra and storing sperm until it is ready to be ejaculated. Sperm passing through the ductus deferens is not yet mobile or able to swim, and thus must be transported via peristalsis. Injury to this content is unable to pass sperm from testes to the ejaculatory duct, cause to Shandata (impotency).

7. Lymphatic Vessels - Due to genital lymphedema unpleasant pain and feeling of heaviness persist. Which causes the ill desire to have intercourse and ultimately develop temporarily to impotency until the problem facing remedy.

Injury to this Marma can produce infertility in the case of males because of the above-mentioned contents of the spermatic cord, in the case of a female because of the content of the round ligament. In males after trauma on Vitap Marma leads to Vaikalya that is Shandata (sterility) or Alpashukrata (oligospermia) and in females cause to prolapse of the uterus as round ligament damaged and ultimate effect will be in difficult to the conception of pregnancy. The superficial inguinal ring is the triangular gap in the aponeurosis of the external oblique muscle. It is also Marma ashritasira, so it should not be punctured. Vitap Marma is described under Sira Marma by Acharya Vaghbhata and Snayu Marma by Acharya Shusrut with a dimension of one Angula (Area of one finger). The position of Vitap Marma mentioned by Acharya is the joining area of Vankshan and Vrishna. According to modern science, that region is accompanied by an inguinal region. Commonly injury of Vitap Marma is caused by surgical trauma, accidental trauma, torsion induced trauma and vas deference injury during herniorrhaphy leads to obstruction and thus sterility. Inflammatory pathogenesis of the cord also causes sperm flow obstruction. Torsion or twisting of the cord leads to sterility by obstructing the pathway of sperm flow.

\section{CONCLUSION}

Each of the content of the spermatic cord described above is responsible for creating such advocacy of Sushrut. Alpashukrata (oligospermia) and Shandata (sterility) are the Viddha lakshans (trauma effect) of Vitap marma. According to modern, this site can be correlated to the inguinal region in which the inguinal canal is present just above the medial half of the inguinal ligament. Trauma to the inguinal canal can cause injury to the contents in the spermatic cord in males or round ligament in the female which leads to subluxation of the uterus and ultimately oligospermia or sterility.

\section{REFERENCES}

1. Kaviraj Dr. Ambika Datt Shastri, Sushrut Samhita, Chaukhambha Sanskrit Sansthan, Varanasi 2019 vol.1 SharirSthan 6/3.

2. KavirajDr. Ambika Datt Shastri, Sushrut Samhita, Chaukhambha Sanskrit Sansthan, Varanasi 2019 vol.1 Sharir Sthan 6/16.

3. KavirajDr. Ambika Datt Shastri, Sushrut Samhita, Chaukhambha Sanskrit Sansthan, Varanasi 2019 vol.1 Sharir Sthan 6/6.

4. J. N. Mishra, Marma and its Management, Chaukhambha Orientalia, Varanasi, 2005 Page 114.

5. B.D. Chaurasia, HumanAnatomy, vol. II, $4^{\text {th }}$ edition, CBS Publishers and Distributors Pvt. Ltd. New Delhi,2004, Page 208,209, 363.

\section{Source of Support: Nil Conflict of Interest: None Declared}

How to cite this URL: Rajesh Kumar et al: Scientific Study Of Vitap Marma. International Ayurvedic Medical Journal \{online\} 2021 \{cited December 2021\} Available from: http://www.iamj.in/posts/images/upload/3017_3020.pdf 